\title{
HUMAN SECURITY AND «EXCLUDING INCLUSION»: THE FRONTIERS IN THE ACTIVE AND PASSIVE CITIZENSHIP EXERCISE
}

\section{GABRIELA PALAVICINI CORONA}

\begin{abstract}
:
This article considers two current topics: citizenship and security, in relation with a phenomenon denominated here as «excluding inclusion» (Agamben, 2003: 38). The first topic emphasizes the active participation while the second one, conceived as human security, highlights the acceptance of oppression due to fear and/or insecurity, in accordance to diverse situations in which an individual can be involved. Thus, human security will be studied as one of the main elements required by the exercise of democracy, devoted to its basic principles. In this sense, a democracy needs some givens to exist. Therefore, human security reinforces an active citizenship or even a critical citizenship, whereas an «excluding inclusion» provokes a lack of citizenship, or even a limited one as a result to the prevailing conditions of being marginalized. This provokes that both variables are considered as mutually exclusive, with direct consequences in the participation and involvement in the decision making process from a State. Hence, the guiding research question will be: How to constitute true active citizenship in the midst of pseudo-inclusive processes? As a hypothesis to solve this query, we would propose that: There is a positive proportional relation between security of any kind and the rise of participation and development; thus, the absence of security, specifically of human security brings to those who undergo it, to allow acts of «excluding inclusion». As a consequence, they become less active or participant. In this sense, is the latter type of inclusion an unavoidable obstacle in the construction of citizenship? Does human insecurity firstly drive to the acceptance of «excluding inclusion», and then to its consequential lack of security, that finally develop a vicious cycle? How to reconcile democracy, human insecurity, and a kind of inclusion that differentiates between the citizen who is currently constructing its economic, social and political community from a citizen who is considered as vulnerable and, therefore, as someone who could be sacrificed? These are also some questions to be considered in the paper.
\end{abstract}

\section{Keywords:}

Human security, citizenship, kinds of citizenship, "excluding inclusion", security

\section{Authors:}

GABRIELA PALAVICINI CORONA, Tecnológico de Monterrey, Mexico, Email: gabypalavicini@hotmail.com

\section{Citation:}

GABRIELA PALAVICINI CORONA (2015). Human security and «excluding inclusion»: The frontiers in the active and passive citizenship exercise. International Journal of Social Sciences, Vol. IV(1), pp. 
72-86., 10.20472/SS2015.4.1.005 


\section{As an introduction...}

Nowadays, the study of democracy and its random perform in those countries that embrace it, has led to highlight the deficiencies and contradictions precisely between its theory and its praxis. Most of all, it shows the conflict between the strict application of its recognized principles, both fundamental and meaningful. As an example, we could emphasize the tension around the exercise of citizenship of those who form part of the population of a State, but whose participation is limited, if it exists, to electoral processes, thus restricting their participation and active citizenship.

The topics to be covered here have been extensively addressed by numerous authors and do not respond to recent problems. The dichotomies security-insecurity and exclusion-inclusion have always been present at any country. We cannot therefore overlook that it was precisely security, or even its absence, what gave origin to the State as it is explained by Hobbes (Hobbes, 2001). His theory will be one of the basis of our theoretical framework. Meanwhile, even when the «excluding inclusion» was not considered as one of the main components of a State, it has arisen steadily as an important element in each State of the world, making more difficult the exercise of citizenship, and thus becoming and unavoidable obstacle. Is it possible to end segregation? To solve this latter question, the analysis proposed here will recall the work from Giorgio Agamben (2003).

It is noteworthy to mention that this study takes place in the context of a democracy, because, in terms of participation, citizenship cannot be conducted in a State that does not belong to this form of political regime. Therefore, even though democracy is not our main topic of discussion, it will serve as a framework because a country's development should be promoted by those who are inside and outside of a State's government, but that indeed form part of a State; these persons are also involved in the design, application and follow-up of public policies to ensure human security. ${ }^{1}$

This work finds its raison-d'être on those democracies showing deficiencies, as their weak citizenship. Studying its causes, such as exclusion, allows us to uncover another set of variables that will lead to a proposal for a review of this process. However, this analysis is not limited to a "passive citizenship" later explained through this text. The concept of security, or actually though security as the absence of criminality is not the one discussed here. Due to this, if human security is considered as a sinequanone for development, then exclusion will become the core concept to study all social problems existing in a national and international level, as: poverty, migration, lack of health, basic services, and scholarly fitted persons, just to mention a few. These are some of the problems that must be reviewed as a form to achieve a better quality of life, and consequently, to improve a commitment in public matters. 


\section{Regarding citizenship, security and «excluding inclusion»}

In this section, we will address these three major topics, as we consider citizenship is the key element to demand its application in different countries, as well as one of the elements that encourages its development, if an increase in the participation in the decision making process is present.

Talking about citizenship nowadays is fairly common. It is a word that has become part of the daily language of both governors and governed, at the international level. However, do we really know what we are talking about? Do we know what being a citizen implies? In most of times, due to a blurry line that separates both concepts, we tend to make equivalent the notion of citizenship with the one of civil society. In order to avoid this inaccuracy, we will develop here the concept of committed citizenship that would, or at least, should lead to the one of civil society. We understand civil society as the organization of society in order to promote its interest, and not as Hegel's conception of the bourgeois civil society in which "all society members seek the accomplishment of their own needs, such as, to live with security, to own certain goods and to lead exchanges not limited to economy but to religion, culture, etc" (Hegel, 2011). Thus, the civil society of which we will be talking about is the one committed towards all of its members, formed by a citizenship concerned with its community and in a broader sense, with the country they belong to. As a starting point, we will begin to talk about citizenship because acquiring human security can enhance it.

What does it mean then to be a citizen? This quality, just as any other, should be cultivated to seize it at its peak, meaning that if it is not exercised, it will get atrophied, thus conducting to a wrong practice or even to its entire absence. Citizenship is a status that is adopted in a "natural" manner, so to speak, while arriving at a certain age, 18 or 21 depending on the country we are dealing with, by being recognized by the Constitutions. This condition springs from the very fact of being born in a given country, who will at its time bestow this condition once certain requirements are covered. In this sense, citizenship is obtained, not asked for. Therefore, citizenship can be exercised in those territories with outstanding participation and cultural endorsement, avoiding those cases in which being a citizen is nothing more than a label and where the individual scope focuses on his own progress.

Being a citizen is an acquired status but it implies a huge difference between being one and just being part of the population, a distinction that arises legally once a person becomes old enough to be considered as a citizen. However, it is not only a matter of age. The acquisition of citizenship entails also responsibilities, obligations and rights, whose exercise is an exercise developed from the conscience of belonging to a community. So, this belonging that starts naturally, shall evolve due to the contribution and the involvement of the individuals in the needs of their place of residence, thus 
generating an improvement in the quality of living of both the person and the community. Hence, citizenship is exercised firstly by the voluntary action in order to comply with the law, but also by participating in the betterment of the circumstances of the place of residence. Citizenship, therefore, implies a sense of belonging but foremost of identity, and commitment with the other and its consequential actions, directed towards the development and the common good, thus it has more opportunities to be strengthened in societies that are more egalitarian.

Citizenship is the difference between individualism and collectivity; the first one will prevail in an ambience of self-interest and individual benefits, without the articulation or association with another fellow citizen. The second one shows the recognition of the other through a framework of social organizations, which underpin the civil society that will try to attain common good. As Adela Cortina states it, a citizen is: "the one who talks to and with others, the one who works together, the one who is neither a subject nor a vassal, it is the one who assumes the protagonism of his own life" (Cortina, 2003). Hence, the concept of citizen that will be used here is the one that recovers the three first dimensions of Cortina's concept: the legal protection of the individual inside its territory; the political participation; and the social dimension, "through which the citizen will assure the protection of his second generation rights"(Cortina, 2003); this social dimension is important in the sphere of justice, defined as the "adequate distribution of rights and duties by the institutions that establish the basic framework of society" (Caballero, 2006: 5). "Justice as "fairness" is based in two principles: the guarantee of basic liberties that coexist with everyone else's rights, and that must fulfill two other conditions: to be associated to open positions for everyone in equal opportunities, and to maximize benefits of societies' less fortunate." (Rawls, 1999: 52-53). As a result, it is impossible to separate citizenship from justice, in which the last one, at its turn, should be the end of civility. The relationship between citizenship and justice is a form to exercise equality in political terms and equity in the economic realm, that at the end will allow the integration of people living inside the same territory, regardless of their origin or customs, specially in the case of those societies that have more than one civilization living together, as almost every society nowadays; a coexistence that takes place under rules and norms. In this sense, Hobbes argued that justice emerges from the Law of Nature, "[f]or where no Covenant had preceded, there had no Right of been transferred, and every man has right to everything; and consequently no action can be unjust. But when a Covenant is made, then to break it is unjust; and the definition of injustice is no other than the not performance of Covenant" (Hobbes, 2001: 118).

The concept of citizenship implies "to consider other essential elements such as a citizenship aware of a self-consciousness, to be conscious of the other and of the entire community to which one belongs; the dichotomy between trust and distrust in the rest of the citizens, as well as in its representatives, in accordance to the interaction with them; the lack of responsibility towards a culture of responsibility, and the element that will allow 
the development of each individual: education" (Palavicini, 2014). This arises another question: Is the practice of citizenship a cultural trait? In other words, does it depend on other elements such as political regime, education, economy and the human security offered by States, or is it inherent to the individual, who seeks to participate, detached from the aforementioned factors? This will also lead us to classify the exercise of citizenship depending on the degree of involvement of the population in the decision making process regarding the public sphere, and considering the consequences experienced directly by both, the individual and his community:

1. Active citizenship.- Recalling the concept from O'Donnell (O'Donnell, 1994), this type of citizenship emphasizes a straight participation in the process of taking decisions, besides the continuous and constant involvement in all the activities related to the population. An example of this citizenship could be found in Switzerland. Active citizenship is equivalent to an integral citizenship, "with full recognition of political, civil and social citizenship" (O'Donnell, 1994: 26), as long as it covers certain characteristics that can only arise warranted by specific pre-conditions such as those related to "human development: food, health, housing and education" (Palavicini, 2004). Thus, it assumes that democracy leads to development, even though there is not a direct correlation between these two variables.

2. Feeble citizenship.- In here we have the self-recognition of the population as "citizens," by covering the legal requirements. Nevertheless, their participation is limited, which in most of the cases only emerges in electoral processes, and even in these instances, not all the people participate. Besides, they are not involved in the task of taking decisions performed by the State. This is the case of Mexico. As an example of this behavior, there are numerous civil associations that have appeared lately, mainly as a result of current insecurity issues. These associations, as part of the organized civil society, identify themselves as a form of an exercise of citizenship that could be institutionalized or not. However, these organizations do not imply any action neither in The Union Powers nor in other governmental institutions, thus remaining inefficient. In this sense, these associations, as well as the government, do not offer results in terms of the transcendence of actions regulated by the law, as if it is not observed cautiously, it will lead to the punishment of people who does not obey the established behavior.

3. - Passive citizenship.- In this case, even when the population perceives itself as citizens, once that they have fulfilled certain characteristics, they still do not participate. In here, we would find countries that have a dictatorial or an authoritarian form of government, thus inhibiting its population to participate, and to even get involved in the decisions making process pursued by the State. This kind of citizenship is more an apparent and formal one, than a real and de facto one, as could 
be the case of Cuba. It is a context in which no one knows what to do or how to practice citizenship.

In this way, citizenship is linked with its practice in the prevailing possibilities to carry it. In this sense, it depends on the context that defines both, the way we act, and specially the way we think, which also depends on the political, economic and social development. Hence, the nature of the citizens is a predominant factor in their behavior as such towards their society; therefore, the analysis is focused on the atomization of the citizen. This is, whether each individual perceives himself in this way, independent from the rest, or whether each one sees himself as to be connected with his peers. Regarding this, Thiebaut has pointed out in relation to communitarians that "they have stressed and continue to stress that the citizen of complex societies cannot be understood without taking into account the social links that make him, precisely, a subject" (Thiebaut, 1998: 39). This also determines the way in which the citizen manifests, which is different in every country, and is related with the auto-conception of the individual in terms of his relationship with the others. However, as all universal concepts, citizenship is founded in the aforementioned dimensions amongst many others, defined by Cortina herself (Cortina, 2003). Nevertheless, according to Thiebaut, being conscious about the existence of the other also implies realizing their differences, which will ultimately mean to accept them as variables that underpin particular identities. This by acknowledging that the praxis, derived from a critical thought, conscious of diversity, brings the person to develop both an image about himself and his environment. As a result, this generates a kind of compatibility, as it consciously faces difference, pushing forward to a higher dimension that allows discerning between an individual and a citizen: the private and the public spheres, respectively. Finally, we can transit from the private identity to the public one, which also implies the other as well as the responsibilities owed to him. In this sense, Thiebaut says that:

"Being a citizen is to belong and to support (...) belonging to a city is not a passive action, but rather a powerfully active one: the citizen is made by him making his city; he is not an object of possession of the thing-city, he belongs to a system of actions from which he himself is a source. The aim of an action is not

what a citizen does (in the city), but to become a citizen; to construct the city is the way in which one becomes its citizen (...) Political identity is then derived from our actions: from the exercise that implies our participation in what we do, the city" (Thiebaut, 1998: 25)

in either an environment that supplies the conditions to foster this citizenship, or through an environment that limits it and promotes an «excluding inclusion». It is deemed to be inclusive because, except for a few cases, we are all born in a State and as part of belonging to it, we are subjected by its rules, then we are implicitly considered in its legal framework. However, it is excluding because, in one hand, it does not provide the basic elements for its own growth regardless that such exercise is detailed in its laws and norms, and thus blocking this exercise. On the other hand, and above all, this exclusion prevents the development of the individual inside the community to which he belongs. In 
this sense, a citizen has "to be» and «to act» as a citizen, by showing himself as the "owner» of his rights as part of his possession and praxis, which belong to him as a person and as a fact from his existence, paired up with his development as a human being. In other words, being a citizen implies that the own dignity must be respected, which leads us to another guiding concept of our study: security. What does it mean? Is the association of security and citizenship a determinant element of progress and development of a nation? Is that condition enough or merely a stepping stone in the attainment of development? Before going any further, we shall define this concept, because in a broader sense, it will encompass more than just what emerges facing its opposite: insecurity.

Even if citizenship is an acquired quality, the praxis of citizenship depends not only on the prevailing political regime but also on the political culture each individual has, and above all whether we have the appropriate conditions for development, provided by the State. The exercise of citizenship is found in the middle of bordering concepts: the human security and its limit, a topic that will be developed in the next section. Therefore, the frontier between being a citizen able to participate, and being a discriminated citizen, means that someone can fulfill all legal requirements but be a victim of an "excluding inclusion», which prevents him from converting his reasoning to action, as a result of his will. (Kant, 2007: 248). What happens when the will of a human being is being inhibited by his own context? Will this human being tend to be more passive by not participating, or will he try to break the status quo?

These questions arise because inclusion, diversity and the capability to fully exercise our rights in a community rely on respect and on the form in which the dignity of people is handled. Following this, "the modern assumption of dignity as a right and its subsequent on «equal dignity», Taylor proposes as a counterpoint, his «politics of difference», in which the recognition of the "other» as well as of diversity and its acceptance, are all fundamental elements in the process of understanding the idea of dignity more as a value than as a mere right: dignity, according to Taylor, is a capability that we all share as human beings. It is a "human universal potential» that must be equally respected by all, but that has to include in the form it is conceived some central elements such as the notion of emergence, development and the process of its constitution" (Taylor cited in Thiebaut, 1998: 130). In this sense, we can avoid what makes current States vulnerable: the internal and external conflicts due to the lack of respect of the dignity towards some persons or groups, as well as the awareness of this absence of respect. Therefore, this lack of respect to the other as a human being, raises a wall that highlights the border between the possible and the impossible, between what is considered as far and as close, between reality and illusion; a border between inclusion and exclusion.

As previously seen, the concept of «security» recalls a notion of protection from a given danger, even if it is studied through the perspective of Hobbes. In the case of this author, 
this idea is present when he argues that "[...] as small families did then; so now do cities and kingdoms which are but greater families (for their own security) enlarge their Dominions, upon all pretenses of danger and fear of invasion, or assistance that may be given to invaders (Hobbes, 2001: 138), thus, the need to strive for developing a community becomes crucial in order to protect life and property. The concept of property also comes from this author, who conceives the State as an integrating entity, regardless of the apparent loss of freedom that the individual might suffer in the sense that his liberty seems to dilute in the midst of laws and the others, while at the same time it also increases as he develops the capability to direct his actions for his sake and the one of the community where he belongs. So, as Hobbes argues, in the res pública, a concept that could be also identified as common power, the individual is able of evolving in an ambience of equality, justice and certitude of both, his life and his belongings. Furthermore, this author differentiates between the public and the private spheres, setting apart the individual from the particular process of making decisions. As a result, this also leads to distinguish between the individual interests from the collective one.

The concept of security was used up until the 1990's in the sense that Hobbes had thought about it by conceiving the man in a state of nature, thus having to protect himself from both internal and external threats of invasion; this notion derives in the concept of national security as understood during the Cold War. Therefore, this concept made reference to the protection of what was considered as national and particular property, and it should also protect both, the individual and his property. Nowadays, this arises as one of the challenges that every State has to face.

By analyzing the meaning of security, we realize that it is understood as the absence of risk, which implicitly leads to "certainty», "certitude» in any aspect, individual or collective; in acquiring a job, a good, in life preservation, in having what is required to have a level of life that can develop, by having already covered the basic needs, towards Maslow's conception of self-realization (Maslow, 1943: 370-396). However, it is noteworthy that even Maslow includes a notion of "security" in his hierarchy of needs, a notion that he understood as the "physical security, of employment, of moral, family and health resources and of private property" (Maslow, 1943: 370-396), which allows us to say that the feeling of being risk-free is, among some other things, the certainty of having the means to provide ourselves with what we already mentioned. In this sense, the certitude of well-being fulfilled through these aspects will lead us to the concept of security as it will be applied in this paper: the one of human security, understood also as the absence of uncertainty and, as a consequence, of fear for the lack of the aforementioned goods. This human security is accomplished due to the framework of institutional infrastructure, planning, public policies and follow up provided by the State. These conditions are also known as an efficient governance of given resources that should generate other resources from them. This concept of human security was created 
in the very recent year of 1994 (UNDP, 1994), by the United Nations Development Program (UNDP), as part of its Second Report on Human Development, which states that in order to achieve this kind of security, there should be a sustained development oriented towards the progress of the individual in his society. Here we would like to add that once the active citizenship is achieved, the individual will be able to contribute along with the rest of the members of the State towards the evolution of his society. In this sense, Kofi Annan made reference to this type of security in his speech of 2005, by expressing that development "is only possible in conditions of freedom and that people can only benefit from political freedom if they have at least a good possibility to achieve a decent standard of life (Annan, 2005: 2).

For this reason, one main controversial issue is the fact of providing security for citizens as well as endorsing a form to access it. The absence of security as well as other concerns that usually were considered to be in between the borders of a National State, now have become international issues because they are part of the problems that attack all the countries and whose internationalization aggravates them, as a consequence. One example of this situation could be the problem of drug and weapon trafficking among countries. If it could be enclosed to a specific zone between countries, or even in just one country, then it would be easier to quickly tackle this problem. As the Report says, "the threats to human security are no longer just personal or local or national. They are becoming global: with drugs, AIDS, terrorism, pollution, nuclear proliferation. Global poverty and environmental problems respect no national border. Their grim consequences travel the world" (UNDP, 1994:2).

Thus, the emergent difficulties, as those mentioned before, do not reinforce a proper governmental administration in order to achieve a better life standard for their acknowledged population. This also prevents the individual to achieve what Kohlberg calls «the stage of ethical-universal principles», identified as part of the post-conventional level of moral development, a stage that highlights the social agreements between individuals, (Kohlberg, 2002: 1) and prevents that citizenship is only carried on completely as a full exercise of rights and obligations attached to fear. Under these circumstances, instead of decreasing the risk of supporting those difficulties by increasing the sense of security in certain aspects, it seems that the risk actually gets stronger due to the "excluding inclusion» that inhibits equality; besides, the so called sense of security is considered as a minimal element, especially in those States that have an inefficient governmental administration and a weak institutional infrastructure in project planning, public policies, accountability and inefficient results.

Hence, human security is relevant due to the daily fears of the society in which we live in. These fears affect everyone equally, one way or another, as they also affect the core of different states: "human security is relevant to people everywhere, in rich nations and in poor. The threats of the security may differ -hunger and disease in poor nations and 
drugs and crime in rich nations [...] some threats are indeed common to all nations -job insecurity and environmental threats, in particular."(UNDP, 1994: 3) These threats must be eliminated or at least diminished in order to actually reach human security, in a broader sense, "security facing hunger, sickness, crime and repression, side by side with protection from daily life happenings" (UNDP,1994: 3).

Due to this, at an international stage, human security has become an imperative for development, from which a minimal starting point is required to guide public policies towards diverse basic and non-basic areas, such as the ones we have talked about. Notwithstanding, even when all countries are involved and their problems affect each other, they also share the responsibility to solve those problems. This responsibility does not imply a division of tasks or duties; instead of, it highlights the commitment from each part to address a solution. In spite of this, we cannot ignore the responsibility that every State has with its own population, because the awareness of this duty will allow the State to reduce insecurity levels in some areas, while it will help to stop the increase of insecurity beyond the national boundaries by limiting the problems, besides it will allow to work out a more efficient solution.

Even though ending with insecurity is difficult because it implies internal changes that must take place inside societies, the world juncture does make it necessary for us to reconsider the way we have been trying to achieve development, since in some cases it has brought an economic growth rather than social prosperity. As social prosperity we conceive the inclusion of each and every individual, firstly, as the legal recognition of his citizenship and then, as the exercise of this citizenship in a context in which providing stability to population is a duty, facing an ever-growing uncertain globalized world. Consequently, as the UNDP also considers, "human security requires social contracts at the global level" (UNDP, 1994: 30), in order to fulfill the pact through which we agree to leave the Hobbesian «natural state» towards the State, without forgetting those duties that must happen at the national and local level within each country. In this sense, human security is a concern about cooperation which implies that every State must be involved, thus they should focus their attention in the common good, understood in terms of Aristotle as the "virtue and happiness of citizens"(Aristotle cited in Casar, 2010: 2), in order to avoid the dissolution or obstruction of the social contract that will lead to the discrimination and exclusion of the other, due to the prevalence of a particular interest. In this way, exclusion is also related to intolerant attitudes against whoever is different. As a consequence, there is a tendency to raise, even through a violent form, all social conflicts; besides, this tendency increases the fear of individuals to suffer a specific set of circumstances. Then, the eradication of this fear is exactly the goal to be pursued at the moment we talk about security, as it is settled in the Millennium Report of the United Nations (UN)(Annan, 2000). However, what does exactly cause this fear? Human security implies the development of an individual inside its community, as it also suggests his truthful inclusion, rather than to pretend one that can actually affect all the society and 
that leads to exclusion itself, in accordance to the characteristics of impact and habitus, as they were analyzed by Bordieu (Bourdieu, 1971/1983) and which reflects the State where they occur. To not be considered "part of something» is a feeling endorsed by the lack of human security because, this kind of security helps to overcome any adversity that a person may suffer at a particular context, even if it comes from the interior or the exterior.

Then, the lack of inclusion and tolerance becomes, as Trías pointed out( 2005: 50), "the shadow of politics," as it is forgotten that this shadow includes what implies the polis, and consequently, it also considers those who enable it, as part of setting their relation with the other; through this context, the community stops being a public one as this space founds its limits in the exception and injustice, as well as in the individual and collective fear, instead of highlighting confidence. As Agamben argues, this situation is found through the frailty of the individual's life that can be found on the context where he lives in, as it reflects the conditions considered as part of his zoe and which denies him the access to lead a "politically qualified life». This situation also nullifies the individual's biopolitical condition as it reduces this modern human being, in terms of Foucault, to "an animal that puts at stake his condition as a living being, through the type politics in which it actually lives."(Foucault cited in Agamben, 2003: 11). In this sense, the bio-politics imply the active exercise of citizenship which- as we have stated- can only happen in a State that gives certain conditions for this; a State in which inclusion is real instead of a disguised exclusion, and in which this inclusion is no longer used as a form to maintain the structures of poser. Recalling Agamben, inclusion should be considered as an end in itself; as part of a State that makes no distinction between races, classes or cultures; a condition that helps to eradicate the shady environment that surrounds the public space and affairs of every individual; a condition that faces the uncertainty and the fear of remaining marginalized; it is the border between the achievable and the impossible; a border in the middle of law and fact, of internal and external. This current state of affairs is part of a pendulous context between accessibility and inaccessibility to equality through a legal system, as well as in opportunities. This context is also reinforced by the lack of definition of ideologies and the diffuse practices of modern politics, which enhance security as its counterpart; this same security becomes the beginning of human security, which allows avoiding the state of exception argued by Agamben (Agamben, 2003: 32).

\section{Final reflexions}

As it has been seen throughout this text, security and discrimination are mutually exclusive because if the first one is present, the second one will decrease, or hopefully it will disappear. The inverse relation is also true, because they both are essential elements that allow or prevent life conditions for the evolution of the individual. In this sense, the 
mere presence of a population or citizens who fully exercise their rights, serves as proof of the presence of security or the lack of it.

Population is, in a sense, the primary element of a State. As such, population must be protected through the observation of the laws. The population's development is limited if social fundamental rights are not ensured. Following this assumption, low levels of health and education limit the involvement of population in public affairs, and in citizens' exercise of rights and obligations. Therefore, citizenship is represented through the formation on civic values, which reinforce the commitment with their society. These values are shown in the praxis, but also they depend whether a political culture has been developed or not through the history of the country. This history could manifest vicissitudes due to not only the internal context of the country -as favorable conditions with advantages, or unfavorable ones with disadvantages-, but also influenced by external conditions that, in one form or another, shape the current economic and even political ideologies at a given time, in a global scale. Nevertheless, we cannot forget that democracies need citizen's participation so as to remain a "valid political regime". This means that they should not allow "pseudo inslussive" processes or "excluding inclusion".

However, being a fully active citizen implies the absence of shortcomings and full respect for human dignity; this must be present as a right but also in exercise and practice of the value that it represents. In other words, this implies the total inclusion of this individual in the State's strategies for development. Then, human security should allow an integral development of a country, being both: citizenship and security, the key elements needed to ensure this development. Hence, the inhibition of a person's will through exclusion, or through an apparent inclusion, is going to result in the acceptance of violated rights and limited capability of participation as well as in the absence of order, and feeble citizens who oscillate in between the border of what is possible and impossible, between access to limited opportunities or the lack of them, due to the absence of basic elements composing human security.

\section{REFERENCES}

AGAMBEN, Giorgio, (2003). Homo sacer. El poder soberano y la nuda vida. Valencia, Pre-textos.

ANNAN, Kofi (2000). Nosotros los pueblos. La función de las Naciones Unidas en el Siglo XXI. ONU. Cumbre del Milenio. En:

http://www.un.org/spanish/milenio/sg/report/full.htm (Accessed on December the 7th, 2013).

ANNAN, Kofi. (2005). Informe "Un concepto más amplio de libertad: Desarrollo, seguridad y derechos humanos para todos”. Asamblea General. ONU. 21 de Marzo 
de 2005. En: http://www.un.org/spanish/largerfreedom/webcast.html (Accessed on December the 7th, 2013).

CABALLERO, José. (Otoño, 2006). "La Teoría de la Justicia de John Rawls". En: Voces y Contextos, [En línea] No.II. Año 1, IberoForum. http://www.uia.mx/actividades/publicaciones/iberoforum/2/pdf/francisco_caballero.p df (Accessed May the 25th, 2011).

BOURDIEU, Pierre. (1971/1983). Campo del poder y campo intelectual. Buenos Aires, Folios Ediciones.

CASAR, María. (2010). Sistema Político Mexicano. México, Oxford University Press.

CORTINA, Adela.(2003). "Conferencia Ética, Ciudadanía y Modernidad”. Universidad de Valencia. En:

http://web.uchile.cl/vignette/cyberhumanitatis/CDA/vida_sub_simple3/0,1250,PRID \%253D7562\%2526SCID\%253D7566\%2526ISID\%253D347,00.html (Accessed on April the 11th, 2014).

Hegel,Georg (2011). Los Principios de la Filosofía del Derecho de Hegel. In: http://unizarfilosofia.wordpress.com/2011/01/25/los-principios-de-la-filosofia-delderecho-de-hegel/ (Accessed on April the 14 $\left.{ }^{\text {th }}, 2014\right)$.

HOBBES, Thomas (2001). Leviatán o la materia, forma y poder. México, FCE.

KANT, Immanuel. (2007). Crítica de la razón práctica. Argentina, Editorial Losada.

KOHLBERG, Lawrence. In: http://ficus.pntic.mec.es/ cprf0002/nos_hace/desarrol3.html (Accessed on December the $6^{\text {th }}, 2013$ ).

MASLOW, Abraham. (1943). "A theory of Human motivation”. In Psychological Review,No. 50. pp. 370-396.

O'DONNELL, Guillermo. (1994) "Delegative Democracy". In: Journal of Democracy. [En línea]Vol. 5.No. 41. (accesse on January the 15th, 2014).

PALAVICINI, Gabriela. (2014). "Los jóvenes y la democracia: Retos y perspectivas para el ejercicio de su ciudadanía". En: Políticas Públicas en materia de Juventud. JuventudES Veracruz. Gobierno del Estado de Veracruz, Organización de Estados Americanos. (In publishing).

Programa de Naciones Unidas para el Desarrollo (UNDP) (1994) Informe sobre

Desarrollo Humano. New dimensions of human security. PNUD. In:

http://hdr.undp.org/es/informes/mundial/idh1994/capitulos/

RAWLS, John. (1999). A theory of Justice Gran Bretaña, Oxford University Press.

THIEBAUT, Carlos (1998). Vindicación del ciudadano. Barcelona, Paidós.

TRÍAS, Eugenio. (2005). La política y su sombra. Barcelona, Editorial Anagrama. 
UNICEF. "Los Derechos de la Infancia y Adolescencia en México: una Agenda para el Presente". In: http://www.unicef.org/mexico/spanish/UNICEF_SITAN_final_baja.pdf

${ }^{1}$ In order to avoid confusions around the concept of human security, it is necessary to advice that this text does not cover the concept of human development. As a result we will not dwell on it. 